\title{
GAMBARAN KADAR HEMOGLOBIN PADA PEROKOK AKTIF DI TERMINAL KAYURINGIN KOTA BEKASI
}

\author{
Moudy Ramadhanti ${ }^{1^{*}}$, Ria Amelia ${ }^{2}$, Danny Luhulima ${ }^{3}$ \\ 1. Program Studi DIII Teknologi Laboratorium Medik, STIKes Mitra Keluarga, Bekasi-Indonesia \\ 2. Program Studi DIII Teknologi Laboratorium Medik, STIKes Mitra Keluarga, Bekasi-Indonesia \\ 3. Bagian Patologi Klinik, RS. Mitra Keluarga Bekasi Timur, Bekasi-Indonesia
}

*Korespondensi: Moudy Ramadhanti | STIKes Mitra Keluarga| moudyramadhanti@gmail.com

\begin{abstract}
Abstrak
Pendahuluan: Perilaku merokok berdampak yang buruk terhadap kesehatan. Salah satu zat berbahaya dalam asap rokok yaitu karbon monoksida. Karbon monoksida yang sangat mudah berikatan dengan hemoglobin dibandingkan dengan oksigen maupun karbondioksida. Ikatan karbon monoksida dengan hemoglobin dapat beresiko terjadinya kondisi hipoksia. Jika kondisi ini dibiarkan maka dapat menyebabkan kematian sel. Penelitian ini dilakukan untuk melihat gambaran kadar hemoglobin pada perokok aktif di Terminal Kayuringin Kota Bekasi.

Metode: Jenis penelitian yang dilakukan adalah penelitian deskriptif dengan menggunakan desain penelitian cross sectional. Jumlah responden sebanyak 31 perokok aktif yang diperoleh melalui wawancara dan kadar hemoglobin diperiksa dengan menggunakan alat hematology analyzer ABX Micros 60.

Hasil: Hasil penelitian kadar hemoglobin pada 31 responden perokok aktif diperoleh nilai rata-rata sebesar 14,5 g/dL, dengan standar deviasi 1,0942 $\mathrm{g} / \mathrm{dL}$, nilai tertinggi $16,9 \mathrm{~g} / \mathrm{dL}$ dan nilai terendah $12,3 \mathrm{~g} / \mathrm{dL}$.

Kesimpulan: Berdasarkan hasil tersebut dapat disimpulkan bahwa kadar hemoglobin pada 31 responden perokok aktif masih dalam kadar normal. Kadar hemoglobin normal pada perokok aktif diduga sebagai respon tubuh untuk memenuhi oksigen dan menjaga homeostatis agar metabolisme tubuh berjalan normal.

Kata Kunci: Hematology analyzer, Kadar hemoglobin, Perokok aktif.
\end{abstract}

Diterima 2 November 2019; Accepted 30 Desember 2019

\section{PENDAHULUAN}

Rokok merupakan salah satu olahan tembakau dengan menggunakan bahan tambahan ataupun tanpa bahan tambahan. Rokok mengandung zat adiktif yang bila digunakan dapat mengakibatkan bahaya kesehatan bagi individu dan masyarakat (Makawekes, et al., 2016). Menurut World Health Organization (WHO) pada tahun 2014, kasus endemik tembakau telah membunuh sekitar 6 juta orang pertahun diantaranya merupakan perokok pasif, angka ini diperkirakan akan bertambah mencapai 7 juta orang pada tahun 2020. Data Kementerian Kesehatan RI menunjukkan peningkatan pada tahun 2013 sekitar 16,8\% pada kalangan anak, dewasa laki-laki maupun perempuan (Kemenkes RI, 2016).

Faktor seseorang untuk merokok dipengaruhi oleh beberapa faktor; seperti faktor sosial, faktor farmakologis dan faktor psikologis. Faktor sosial merupakan faktor eksternal yang mempengaruhi sikap seseorang untuk merokok, umumnya faktor sosial ini berasal dari lingkungan sekitar. Faktor psikologis merupakan faktor internal yang mempengaruhi seseorang untuk merokok. Ikatan psikologis dengan rokok dikarenakan adanya kebutuhan untuk mengatasi diri sendiri secara mudah dan efektif. Rokok juga dibutuhkan sebagai alat keseimbangan.

Sopir angkutan umum adalah pekerjaan yang banyak menghabiskan waktu di lalu lintas kota yang memiliki tingkat polusi tinggi. Sehingga membutuhkan kesimbangan untuk menjaga konsentrasi. Masalah yang dihadapi oleh sopir angkutan umum adalah pengoperasian kendaraan rata-rata 12 jam hingga 18 jam. Lamanya jam kerja tersebut dapat menjadikan tekanan yang dapat menyebabkan stress, sehingga mereka cenderung merokok untuk menghilangkan stress. Sopir angkutan umum merokok untuk mencari relaksasi maupun efek reaksi positif yang didapatkan ketika merokok dan menjadi kebiasaan sebagai salah satu pilihan ketika beban kerja atau stress itu meningkat.

Asap rokok mengandung sekitar 4000 senyawa diantaranya adalah nikotin, tar, 3,4-benozopiren, karbon monoksida, karbon dioksida, nitrogen oksida, amonia dan sulfur. Karbon monoksida memiliki afinitas yang tinggi terhadap hemoglobin, sekitar 210 hingga 300 kali lebih besar dibandingkan afinitas terhadap oksigen (Amelia, et al., 2016). Afinitas karbon monoksida yang tinggi terhadap hemoglobin memudahkan kedua senyawa tersebut untuk saling berikatan, sehingga mengurangi kapasitas hemoglobin 
dalam pengangkutan oksigen. Hal ini menimbulkan terjadinya hipoksia jaringan, sehingga tubuh berusaha untuk meningkatkan kadar hemoglobin sebagai kompensasinya. Peningkatan ini dipengaruhi oleh lamanya merokok dan jumlah rokok yang dihisap perhari (Leifert, 2008).

\section{METODE}

Jenis penelitian yang dilakukan adalah penelitian deskriptif dengan menggunakan desain penelitian cross sectional. Penelitian ini dilakukan di laboratorium RS. Rawa Lumbu pada bulan Februari 2018. Populasi yang diteliti dalam penelitian ini adalah sopir angkutan umum yang bertugas di Terminal Kayuringin Kota Bekasi yang memenuhi kriteria inklusi dan bersedia menjadi objek penelitian. Kriteria inklusi yaitu perokok aktif yang merokok 1 hingga 2 bungkus rokok per hari, dan perokok aktif yang merokok lebih dari 10 tahun. Kriteria eksklusi yaitu perokok yang merokok kurang dari 1 bungkus rokok per hari, dan perokok yang merokok kurang dari 10 tahun. Jumlah sampel pada penelitian ini sebanyak 31 responden perokok aktif. Variable bebas pada penelitian ini adalah perokok aktif dan variable terikat adalah kadar hemoglobin. Pengumpulan data dilakukan secara wawancara dan pengukuran kadar hemoglobin responden.

\section{HASIL}

Berdasarkan penelitian yang telah dilakukan didapatkan hasil sebagai berikut:

Tabel 1. Distribusi Kadar Hemoglobin Darah pada 31 Responden Perokok Aktif

\begin{tabular}{cc}
\hline Kadar Hb Darah pada 31 Perokok Aktif & Hemoglobin (g/dL) \\
\hline Rata-rata & 14,5 \\
Standar Deviasi & 1,0942 \\
Nilai Tertinggi (Max.) & 16,9 \\
Nilai Terendah (Min.) & 12,3 \\
\hline
\end{tabular}

Tabel 1 menunjukkan nilai rata-rata hemolobin darah pada 31 responden perokok aktif sebesar 14,5 $(\mathrm{g} / \mathrm{dL})$, dengan standar deviasi 1,0942 (g/dL), memiliki nilai tertinggi 16,9 (g/dL) dan nilai terendah 12,3 $(\mathrm{g} / \mathrm{dL})$ yang masih termasuk dalam batas normal nilai Hb laki-laki.

Tabel 2 Hasil Uji Normalitas Sebaran Data Kadar Hemoglobin Darah pada 31 Responden Perokok Aktif Menggunakan Uji Saphiro-Wilk

\begin{tabular}{lcc}
\hline \multicolumn{3}{c}{ Saphiro-Wilk } \\
\hline & P-Value & Keterangan \\
\hline Kadar Hb darah pada 31 responden perokok aktif & 0,140 & Normal \\
\hline
\end{tabular}

Tabel 2 menunjukkan normalitas sebaran data kadar hemoglobin darah pada 31 responden perokok aktif menggunakan uji saphiro-wilk karena sampel yang diperoleh kurang dari 50. Hasil yang didapatkan yaitu 0,140 . Suatu data dinyatakan berdistribusi normal jika nilai probabilitasnya $>0,05$. Berdasarkan hasil yang didapatkan yaitu 0,140 maka dapat disimpulkan bahwa data berasal dari populasi yang terdistribusi normal.

\section{PEMBAHASAN}

Kadar hemoglobin dipengaruhi oleh banyak faktor seperti umur, jenis kelamin, nutrisi, ketinggian daerah tempat tinggal, kebiasaan merokok, obat-obatan yang dikonsumsi, serta alat dan metode tes yang digunakan (Esa, et.al., 2006). Berdasarkan Tabel 1, rerata kadar hemoglobin dari 31 responden perokok aktif adalah 14,5 g/dL, dengan demikian kadar hemoglobin pada 31 responden perokok aktif masih dalam kadar normal.

Hasil ini diduga karena adanya faktor bias yang telah mempengaruhi hasil seperti faktor kualitas tidur dimana faktor ini telah mempengaruhi kadar hemoglobin responden. Pada penelitian ini, sebanyak 64,5\% responden memiliki waktu tidur 2 hingga 5 jam per hari. Menurut Boedhi \& Darmojo (2011), kualitas tidur yang digambarkan dengan waktu tidur yang kurang akan berdampak bagi tubuh karena proses biologis 
yang terjadi saat tidur akan terganggu seperti proses pembentukkan hemoglobin. Terganggunya pembentukkan hemoglobin dapat menyebabkan penurunan oksigen yang dibawa ke jaringan, sehingga menimbulkan kondisi hipoksia. Hipoksia merupakan kondisi kurangnya pasokan oksigen di dalam sel dan jaringan tubuh sehingga tubuh meningkatkan proses eritropoietin sebagai kompensasinya.

Faktor nutrisi merupakan faktor bias selanjutnya, dimana faktor ini telah mempengaruhi kadar hemoglobin responden. Berdasarkan hasil kuisioner yang didapat, sebanyak 61,3\% responden menyatakan bahwa mereka makan hanya dua kali sehari atau makan hanya ketika mereka lapar saja. Namun makanan yang dikonsumsi cukup memenuhi kebutuhan mikronutrien dan makronutrien, seperti nasi dan sayursayuran (bayam). Hanya 38,7\% responden yang mengkonsumsi makanan cepat saji. Selain itu, responden juga menyatakan bahwa mereka mempunyai kebiasaan minum kopi, namun kebiasaan tersebut diimbangi dengan konsumsi air putih yang cukup. Menurut Sacher \& McPherson (2004), kapasitas eritropoietin untuk menghasilkan eritropoiesis bergantung pada kecukupan pasokan zat-zat gizi dan mineral (terutama besi, asam folat, dan vitamin $\mathrm{B}_{12}$ ) ke sumsum tulang. Apabila sumsum tulang mampu berespons, produksi sel darah merah meningkat.

Jumlah rokok yang dihisap juga menjadi bias dalam penelitian ini. Pada penelitian ini, sebanyak 67,7\% responden menghisap lebih dari 20 batang atau 2 bungkus setiap hari. Menurut Riskesdas (2013), perokok dikategorikan kepada tiga kelompok yaitu perokok ringan, sedang dan berat. Perokok ringan adalah individu yang merokok sebanyak 1 hingga 10 batang rokok sehari, sedangkan perokok dengan kategori sedang mengkonsumsi rokok sebanyak 11 hingga 20 batang rokok sehari. Individu yang merokok melebihi 20 batang rokok dalam sehari dikategorikan sebagai perokok berat. Kebiasaan merokok mempunyai banyak pengaruh terhadap nilai normal hematologi. Merokok sebanyak 10 batang rokok atau lebih dalam waktu sehari akan menyebabkan peningkatan hemoglobin dan hematokrit (Packed Cell Volume).

Penelitian yang dilakukan Asyraf (2010) mengenai hubungan kadar hemoglobin pada kelompok merokok dan kelompok tidak merokok, dimana hasil yang didapatkan pada penelitian tersebut yaitu kadar hemoglobin pada kelompok merokok lebih tinggi dari kadar hemoglobin kelompok tidak merokok, namun kadar yang lebih tinggi tersebut masih berada dalam batas normal. Pada kelompok merokok didapatkan nilai rerata sebesar 13,7 g/dL dan pada kelompok tidak merokok didapatkan nilai rerata sebesar 12,5 g/dL. Dengan demikian, hasil penelitian ini sesuai dengan penelitian yang dilakukan oleh Asyraf yaitu nilai hemoglobin pada perokok aktif masih berkisar normal. Hal ini diduga merupakan usaha tubuh untuk menjaga homeostasis agar metabolisme tubuh seimbang. Namun apabila kondisi tersebut berlangsung dalam jangka waktu yang lama maka tubuh akan kehilangan daya homeostasis sehingga dapat menyebabkan penyakit akibat merokok seperti kanker paru.

\section{KESIMPULAN}

Nilai rerata kadar hemoglobin darah pada 31 responden perokok aktif di Terminal Kayuringin Kota Bekasi adalah 14,5 g/dL. Berdasarkan hal tersebut, kadar hemoglobin masih berada dalam kadar normal. Peneliti berharap untuk penelitian selanjutnya mengenai gambaran kadar hemoglobin pada perokok aktif supaya lebih memperhatikan beberapa faktor yang menjadi bias dalam penelitian ini seperti faktor kualitas tidur dan faktor nutrisi.

\section{REFERENSI}

Amelia, R., Nasrul, E., \& Basyar, M. (2016). Hubungan Derajat Merokok Berdasarkan Indeks Brinkman dengan Kadar Hemoglobin. Jurnal Kesehatan Andalas , 619 - 624.

Asyraf, A. (2010). Hubungan Merokok dengan Kadar Hemoglobin Darah pada Warga dengan Jenis Kelamin Laki-Laki Berusia 18-40 Tahun yang Tinggal di Bandar Putra Bertam, Kepala Batas, Pulau Pinang, Malaysia. Medan: Universitas Sumatera Utara.

Balitbang. (2013). Riset Kesehatan Dasar; RISKESDAS. Jakarta: Balitbang Kementerian Kesehatan RI.

Boedhi, \& Darmojo. (2011). Buku Ajar Geriatri (Ilmu Kesehatan Usia Lanjut) (4 ed.). Jakarta: Balai Penerbit FKUI.

Esa, T., Aprianti, S., Arif, M., \& Hardjoeno. (2006). Nilai Rujukan Hematologi pada Orang Dewasa Sehat Berdasarkan Sysmex XT-1800i. Indonesian Journal of Clinical Pathology and Medical Laboratory, 127-130.

Kemenkes. (2016). Peringatan Hari Tanpa Tembakau Sedunia. Jakarta: Kementerian Kesehatan RI. 
Komalasari, D., \& Helmi, A. F. (2000). Faktor-faktor Penyebab Perilaku Merokok pada Remaja. Jurnal Psikologi Universitas Gajah Mada, 2 - 3.

Leifert, J. A. (2008). Anemia and Cigarette Smoking. International Journal of Laboratory Hematology, $177-184$.

Makawekes, M. T., Kalangi, S. J., \& Pasiak, T. F. (2016). Perbandingan Kadar Hemoglobin Darah pada Pria Perokok dan Bukan Perokok. Jurnal e-Biomedik, 4, 1-2.

Sacher, R. A., \& McPherson, R. A. (2004). Tinjauan Klinis Hasil Pemeriksaan Laboratorium (11 ed.). Jakarta: EGC. 